\title{
Cytotoxic and apoptotic effects of neurokinin-1 receptor (NK1R) antagonist on multiple myeloma cells
}

Elham Razani' ${ }^{1}$ Davood Bashash ${ }^{2}$

1. Department of Hematology and Blood Banking, School of Allied Medical Sciences, Shahid Beheshti University of Medical Sciences, Tehran, Iran. ORCID ID:0000-0001-5556-811x

2. Department of Hematology and Blood Banking, School of Allied Medical Sciences, Shahid Beheshti University of Medical Sciences, Darband St., Qods Sq., Tehran, I.R.Iran,Tel:021-2272115, Email:d.bashash@sbmu.ac.ir. ORCID ID:0000$0002-8029-4920$

\begin{abstract}
Background and Aim: Despite therapeutic improvements in recent decades, multiple myeloma (MM) still remains as one of the leading causes of death all over the world. Previous studies have indicated role of neurokinin-1 receptor (NK1R) in the pathogenesis of cancer. Therefore, we decided to evaluate cytotoxic and apoptotic effects of aprepitant (NK1R antagonist) on MM-derived KMM-1 cell line.

Material and Method: In this experimental study, for assessment of cytotoxic effect of aprepitant on MM cells, KMM-1 (prepared in Tarbiat Modarres University) were exposed to different concentrations of the inhibitor $(5,15,30$ and $45 \mu \mathrm{M})$ and subsequently viability, cell count, metabolic activity, and induction of apoptosis were investigated using trypan blue, MTT, and annexin/PI staining assays respectively. Moreover, in order to examine the molecular mechanism of action of aprepitant in KMM-1 cells, gene expression analysis was performed by real-time PCR.

Results: The results indicated that NK1R inhibition using aprepitant resulted in considerable growth suppression of KMM-1 cells. Moreover, we found that the cytotoxic effects were likely due to cell arrest in G1 phase and induction of apoptosis, as revealed by the increased percentage of annexin-V/PI double positive cells among the inhibitor-treated cells $(\mathrm{P}<0.05)$. Also, RQ-PCR analysis revealed aprepitant changed the ratio of expression of pro apoptotic to anti apoptotic genes by way of alteration in the expression levels of Bax and Bcl-2 $(\mathrm{P}<0.05)$.

Conclusion: The present study highlighted the efficiency of aprepitant in suppression of the growth of KMM-1 cells; however, further studies are needed to determine the safety and efficacy of this agent for the treatment of MM patients.
\end{abstract}

Key words: Multiple myeloma, NK1R, Aprepitant, KMM-1 cell line.

Received: Oct27,2018 Accept:Sep2,2019

How to cite the article: Elham Razani, Davood Bashash. Cytotoxic and apoptotic effects of neurokinin-1 receptor (NK1R) antagonist on multiple myeloma cells. SJKU 2019; 24 (5): $1-11$

Copyright (C) 2018 the Author (s). Published by Kurdistan University of Medical Sciences. This is an open access article distributed under the terms of the Creative Commons Attribution-Non Commercial License 4.0 (CCBYNC), where it is permissible to download, share, remix, transform, and buildup the work provided it is properly cited. The work cannot be used commercially without permission from the journal. 


\section{اثرات سايتوتوكسيك و آيوپيتوتيك مهار كننده نوروكينين - ا رسيتور (NK1R) بر سلول- هاى مالتييل ميلوما}

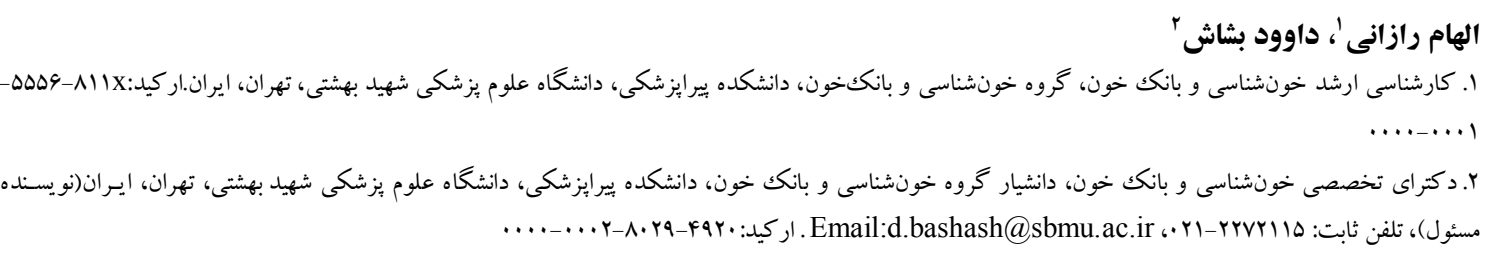

جكيuه

سابقه و هدف: با وجود بيشرفتهاى درمانى در دهه هاى اخير، مالتيبل ميلوما (MM) همجنان يكى از دلايل مهم مـرگك و ميـر در جهان است. بر اساس مطالعات قبلى كه بيانكر نقش Neurokinin-1Receptor (NK1R) در ياتوزنز سرطانها بوده است. هدف ايسن

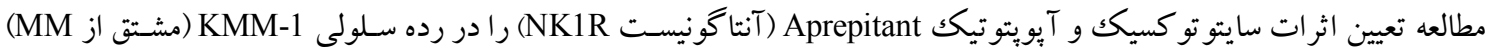

روش بروسى: در اين مطالعه تجربى، براى بررسى اثـرات سايتوتو كسـيك Aprepitant در مالتيـل ميلومـا، رده سـلولى KMM-1

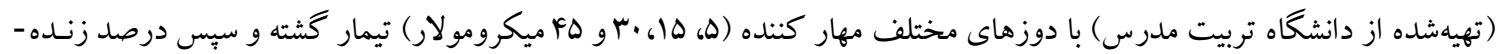

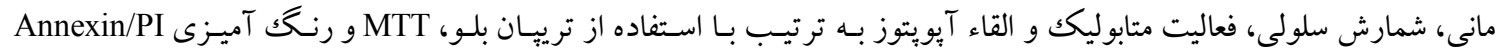
Aprepitant جررسى گرديد. علاوه بر اين، آناليز بيان زُن به كمك تعيين مكانيسم مورش Real-time PCR در سلولهاى KMM-1 انجام شد. يافته ها: نتايج نشان داد كه مهار NK1R با استفاده از Aprepitant موجب مهار رشد سلولهاى KMM-1 مىشود. همبجنين مشاهده شد؛ اثرات سايتوتو كسيك دارو ناشى از توقف سلولها در فاز G1 و القاء آيويتوز است؛ جرا كه درصد سلولهاى رنگك كرفته با

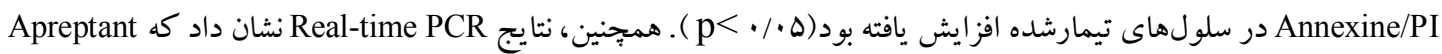
نسبت بيان زنهاى برو آيو يو تيكك به آنتى آيويتو تيك را از طريق تغيير بيان Bax و Bcl-2 تغيير مىدهد. نتيجه تيرى: در اين ثزوهش، كار آمدى Aprepitant در سلولهاى KMM-1 كاملاً مشخص شد؛ با اين وجود، براى تضمين بى خطر و مؤثر بودن اين دارو در درمان بيماران MM نياز به انجام مطالعات بيشتر در آينده است. كلمات كليدى: مالتيل ميلوما، NK1R

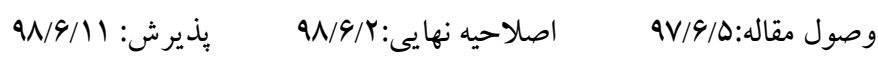




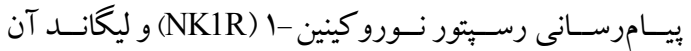

مقدمه

عـلاوه بــــ تنظـــميم بسـيارى از اعمــال Substance P (SP) مالتييل ميلوما (MM) Multiple Myeloma) نوعى بـدخيمى فيزيولوزيكك مرتبط با سيستم عصبى مركزى و محيطى، قابليت است كه با اختلال در مر احلـ انتهايى تمـايز پِلاسماسـلهـا

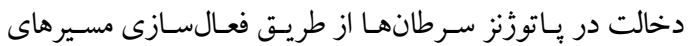
شناخته شده و تجمع كلونال اين سلولها رادر مغز استخوان زيردست خود را نيز دارا است(م). افزايش بيـان ايـن رسيتور و به دنبال دارد. بيش از ...... نفر سالانه در سراسر جهان بـه ليكاند آن در برخى از تومورها به اثبات رسيده است. همجنين، بيان NK1R در لنفوسيتهاى B و T و بيان SP در بلاستهـاى بيمار ان لوسمى لنفوبلاستيك حاد گزارش شده است(9). يكى اليى از مهمترين آنتاكونيستهاى NK1R داروى Aprepitant است كه در حال حاضر جهت درمان تهوع و استفراغ حاد و تأخيرى ناشسى از شـيمىدرمـانى در بـالين كـاربرد دارد. عـلاوه بـر ايسن،

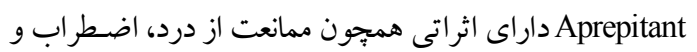
همجنين حفاظت از كبد و سيستم عصبى است.در كنار تمامى

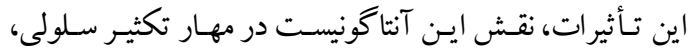

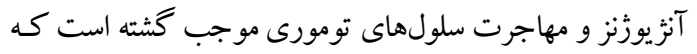

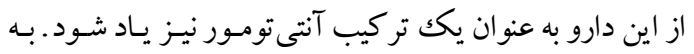
عنوان مثال اثر ضدسرطانى Aprepitant در سرطان سينه (. (1)،

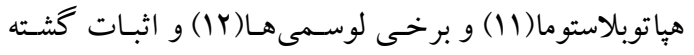

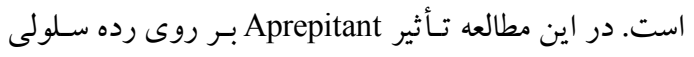

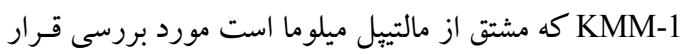

\section{روش بروسى} كثـت و تيمـار سـلولى: در ايـن مطالعه تجربى، سلولهــاى KMM-1

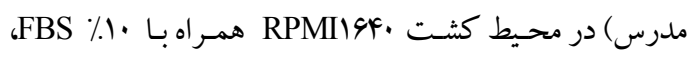
ينى سيلين و U/mll..

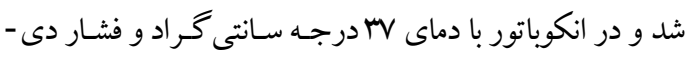

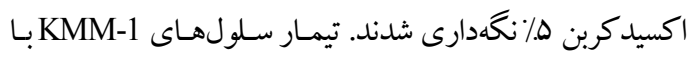

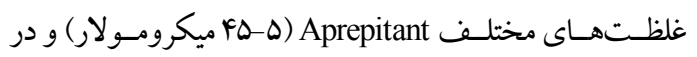

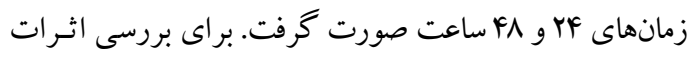

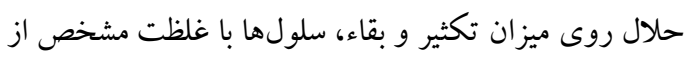
عنوان مورد جديد مبتلا به مالتييل ميلوما تشخيص داده شـده و اين بيمارى دومين بدخيمى هماتولوزيكك شـايع در جهان است(1). مبتلايـان بـه ايـن بيمـارى اغلـب بـا علائسم بـالينى فئى

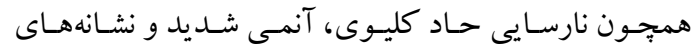
حاكى از بيمارىهاى استخوان به مراكز درمانى مراجعه مى -

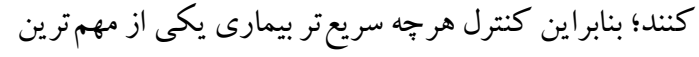

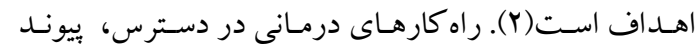
سلولهاى بنيادى و شيمىدرمـانى بـا دوز بـالا استـ(r) كـه ريشه كنى سلولهاى ميلومايى از طريق مصرف ايسن داروهـا به ندرت امكانيذير است. همجنـين، بخـش عظيمى از ايسن بيماران سر انجام به تركيبات دارويسى مـورد استفاده مقـاوم

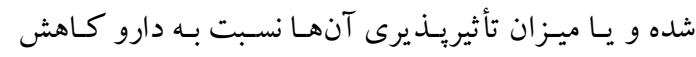

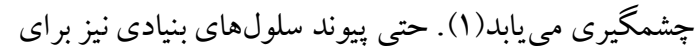

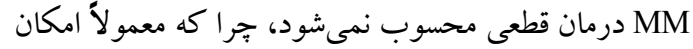

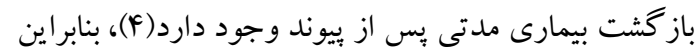

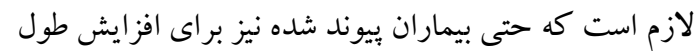

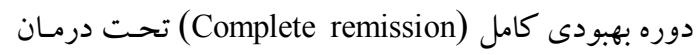

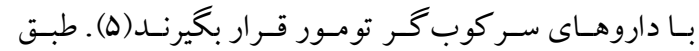
تحقيقات صورت گرفته روى بيماران MM مشخص گرديد كه تنها 94/ از اين بيماران با كمكك درمانهاى فعلى بهبود يافتند و همجنان بخش قابل توجهى از آنها غيرقابل درمـان

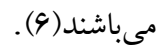
شناختهاى نوين در خصوص مكانسيم بـروز و بقـاء تومسور تو انسته است راه كشاى اميدبخش براى دست يابى به درمان -

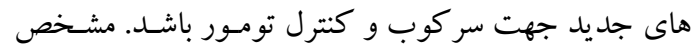
شده است كه فعاليت بيش از حد مسيرهاى بيـامرسـانى كـه ونه

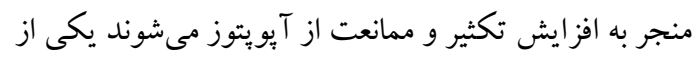

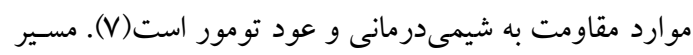

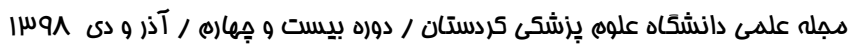




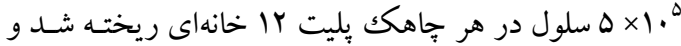

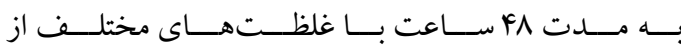
داروى Aprepitant تيمـار گرديسـ. بـس از شسـتوشـوى سلولها با بافر فسفات - سالين (PBS) و افزودن معرفهـاى (Roche) AnnexinV-FITC/PI نمونهها به مدت ها دقيقه در تاريكى و در دماى اتاق انكوبه

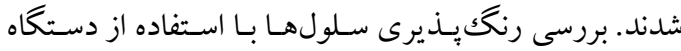
فلوسايتومترى (PartecPasIII) و با طول مـوج تحريـك FM نانومتر و بازتابش 11 اهـ نانومتر انجام گرفت. تجزيه و تحليـل دادهها توسط نرم افزار .9V. Flowjo صورت كرفت. KMM-1 بررسى ميز ان فعاليت جرخه سـلولى: سـلولهـاى

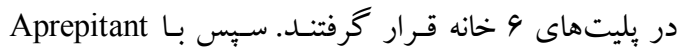
براى مدت زمان FA ساعت تيمـار شـده و يـس از كذشـت زمان انكوباسيون، سلولها با دور ....rpm بر اى زمان هـ

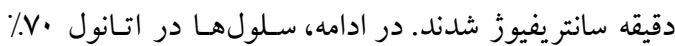

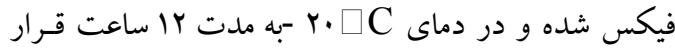
كر فتند. سيس M

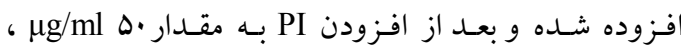
محتويات DNA سلولى بهوسيله فلوسايتومترى مورد مطالعه قرار گرفت و آناليز آن از طريق نمودارهاى به دست آمده

$$
\text { صورت يذيرفت. }
$$

استخراج RNA و سنتز CDNA: يس از تيمار سلولها بـا دوز هو ها ميكرومـولار Aprepitant، اسـتخراج RNA يسس از كذشت \& \& ساعت بـا اسـتفاده از ترايـزول صسورت كرفت. كميـت و درجسه خلـوص RNA اسـتخراج شـــه، بـه روش Nanodrop Y.... اسطيكتروفتومترى و با اسـتفاده از دسـتخاه ND بررسى شد. جهت انجام واكنش رونو يسى معكس از

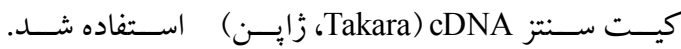

بررسى كمّى بيان زُنهاى Bax و r-Bcl- : براى بررسسى كمّى

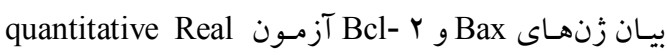

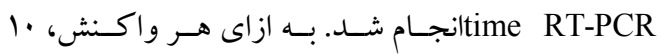
ميكروليتـ (Amplicon) SYBR green master mix
- به عنوان كنترل منفى تيمار شدند. تمامى آزمايش DMSO ها به منظور افز ايش دقت كار به صورت سه كانه انجام شد. آزمون ترييانبلو: جهت بررسى تأثير داروى Aprepitant بـر

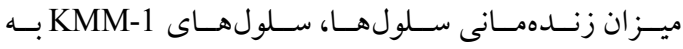
تعداد 5.4× 5.5 cells/ml در حضور دوزهاى مختلـف دارو

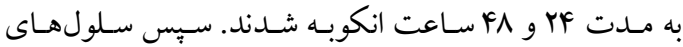
تيمار شده در زمان مقـرر بـا نسـبت ا بـهـ ا بـا رنـكَ حيـاتى

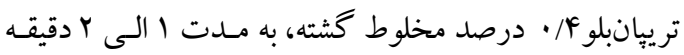
انكوبه و يس از آن شمارش شد. سلولهايى كه اين رنگك را جذب مىنمايند، جزء سلولهاى مُرده و سلولهايى كه هـيج رنكى را به خود جذب نكردهاند، زنده محسـوب مسىشوند.

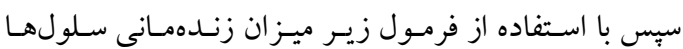
محاسبه كرديد:

ميز ان زندهمانى (٪) = = تعداد سلولهاى زنده ب تعـداد كـل سلولها × . 1. 1.

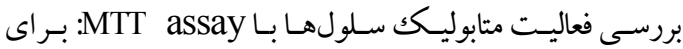

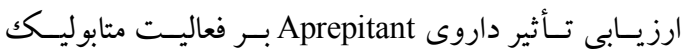

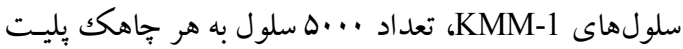

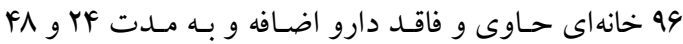
ساعت در انكوباتور CO دار انكوبـه شـد. پـس از گذشـت مدت زمان مورد نظر، به سلولهاى داخل بليـت محلـول 5 5.

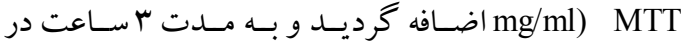

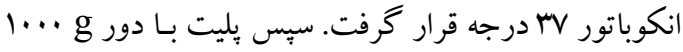
به مــات · ا دقيقـه سـانتريفوز شـده و يسس از خـالى كـردن محلول رويى، · · إميكروليتر DMSO به هر جاهك اضـافه

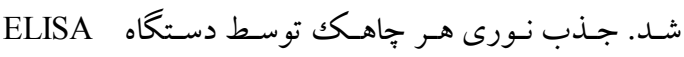
reader در طول موج ·لVه نانومتر قرائت شد. بررسى شاخص آيويتوز با استفاده از فلوسـايتومترى: بـه منظـور بررسى تأثير دارو بر القاء مـرگك سـلولى برنامـهريسزىشـده، جهت سنتز cDNA مطابق با بروشور، نمونسهــا بـه مـدت هات دقيقـه در MV درجسه سـانتى گـــاد و ها ثانيسه در هN درجسه سانتى كر اد انكوبه شدند.

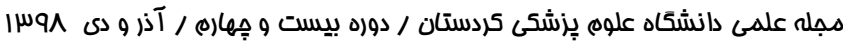




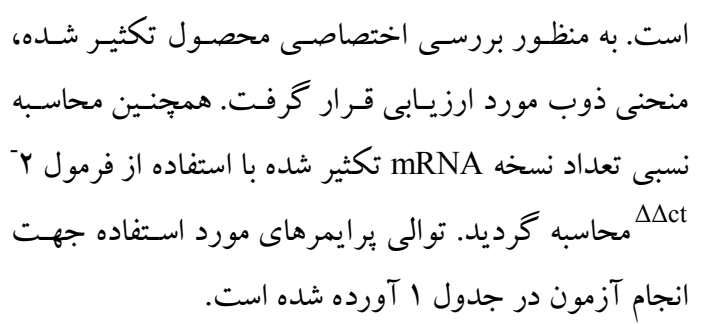

جدول ا. توالى برايمرهاى به كاررفته در آزمون Real Time Quantitative RT-PCR.

\begin{tabular}{|c|c|c|c|c|}
\hline زن & $\begin{array}{c}\text { Accession } \\
\text { number }\end{array}$ & آغازگ معكوس ('3- '5) & آغازگر مستقيم ('3-'5) & $\begin{array}{l}\text { سايز } \\
\text { (bp) }\end{array}$ \\
\hline HPRT & NM_..194 & CCAGCAGGTCAGCAAAGAATTTA & TGGACAGGACTGAACGTCTTG & 111 \\
\hline Bax & NM_IrAvg. & GTGGGCGTCCCAAAGTAGG & CGAGAGGTCTTTTTCCGAGTG & YFY \\
\hline Bcl-r & NM_...994 & CGGTTCAGGTACTCAGTCATCC & CGGTGGGGTCATGTGTGTG & rFq \\
\hline
\end{tabular}

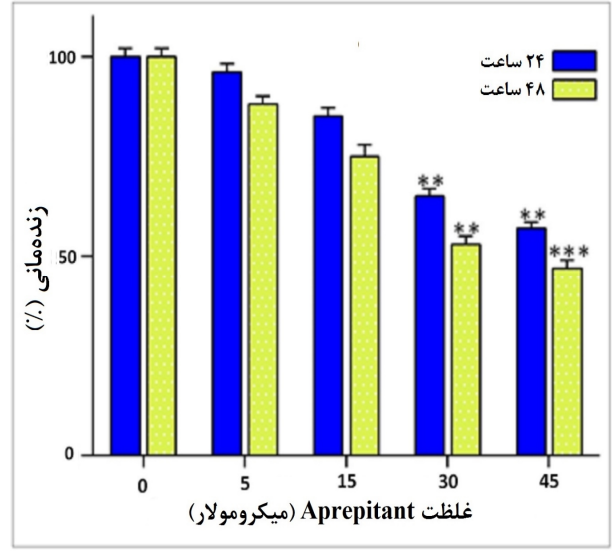

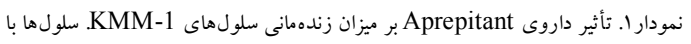

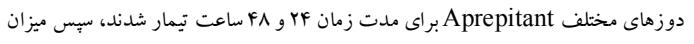

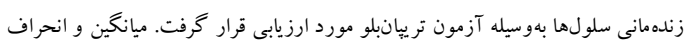

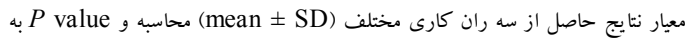

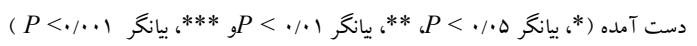

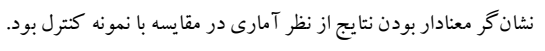

آناليز آمارى: تمامى آزمايشها به شكل سه آزمون مستقل انجام

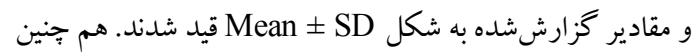
براى محاسبات آمارى از روش Repeated measure

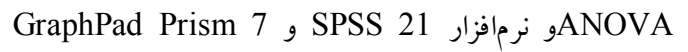

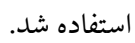

\section{يافته ها} Aprepitant KMM-1 بهصورت وابسته به دوز و زمان مىشود: نتايج حاصل از تست زنده مانى سلولهاى تيمار شده با دارو در كنار گروه كنترل نشان داد كه ميزان زنده مانى سلولها در تيمار YA ساعته با دارو نسبت به تيمار YF ساعته كاهش شديدترى يافته بود. همجنين مشاهده شد علىرغم اينكه دوز ه ميكرومولار از Aprepitant اثر جشم گيرى بر ميزان زندهمانى سلولهاى KMM-1 نداشت، تيمار KA ساعته

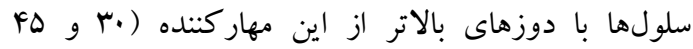

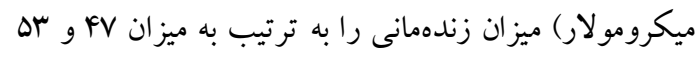
درصد كاهش داده بود (نمودار ().

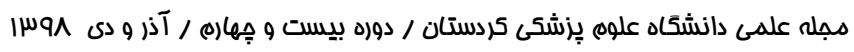


درحالى كه اين عدد بر ای دوزهاى يايين تر شامل ·"ه هاو هـ ميكرومولار به ترتيب داراى يكك رونـد افزايشى بـوده و در

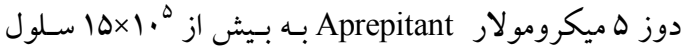
رسـيد. اتـرات آنتسى بروليفراتيـو داروى Aprepitant روى

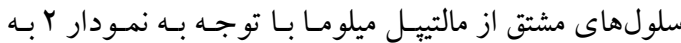

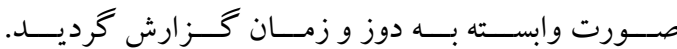

تيمار سلولهـاى Aprepitant بـا داروى منجـر بــ كاهش ميزان تكثير سلولها به صورت وابسته به دوز و زمان مىشود: نتايج حاصـل از شـمارش سـلولهــاى زنــده بعـد از مواجهه با داروى Aprepitant با انكوباسيون به مدت زمـان هاى FF و FA ساعت نشان داد كه ميز ان شـمارش سـلولى در

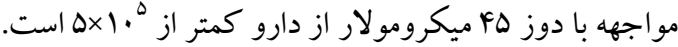

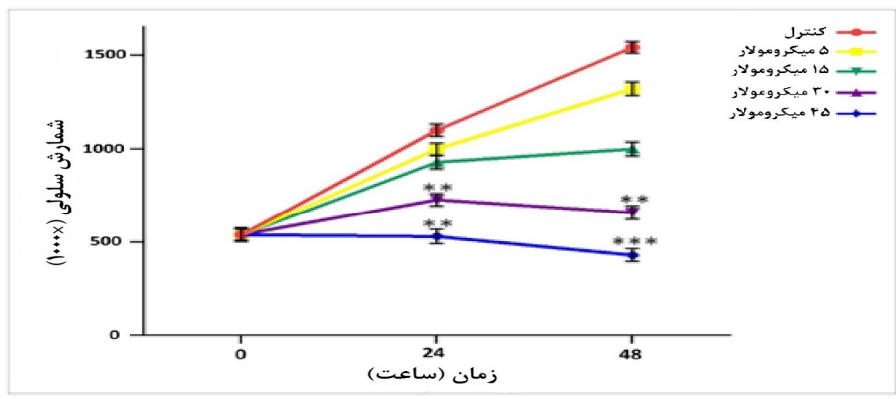

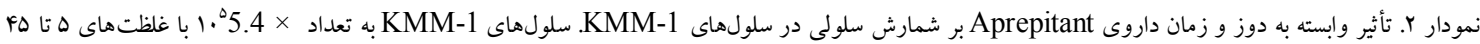

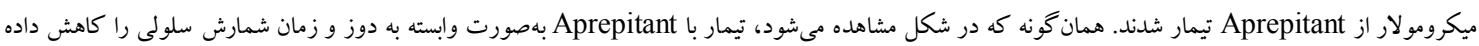
است. ميانگين و انحر اف معيار نتايج حاصل از سه ران كارى مختلف (mean \pm (mD) محاسبه و

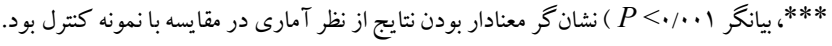
Aprepitant

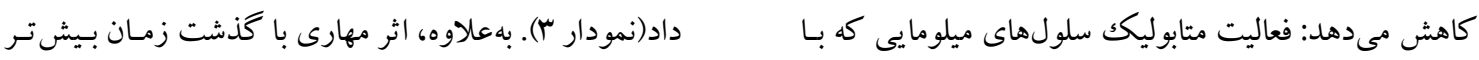

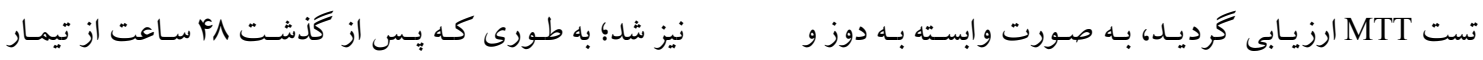

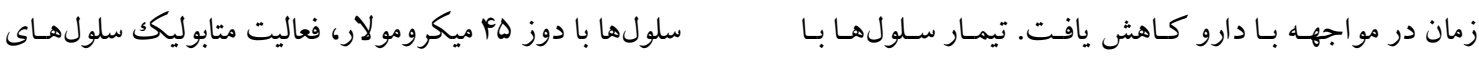

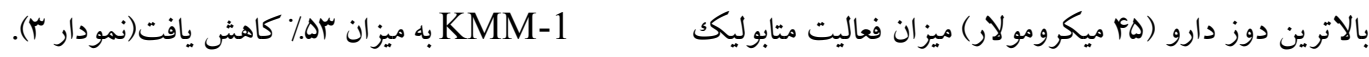

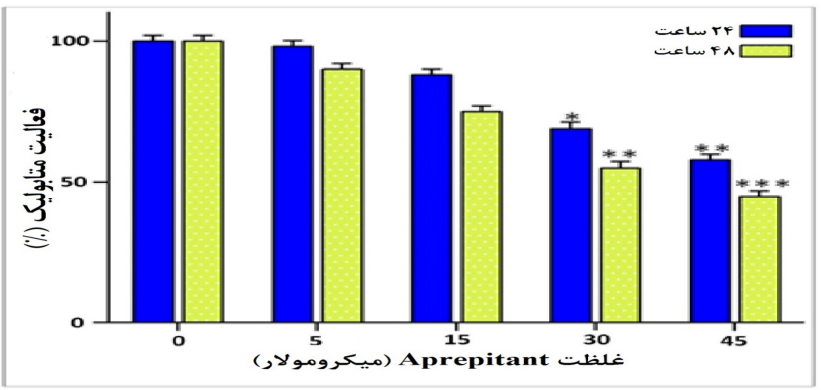

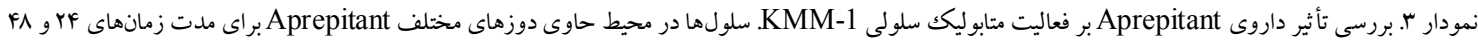

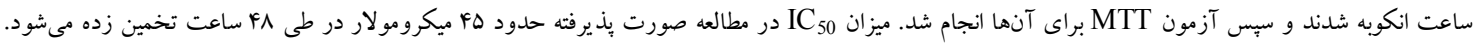

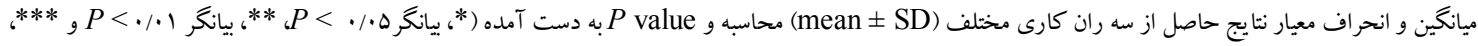

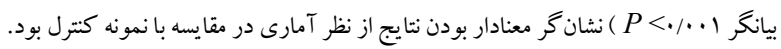


Aprepitant حاضر در فاز Sub-G1 جرخه سلولى (بيانكر سلولهاى در

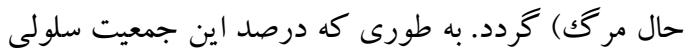
در دوز ها ميكرومولار دارو در مقايسه با گروه كنترل از

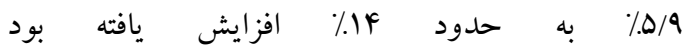

Aprepitant فاز G1 جرخه سلولى مىشود: در اين مطالعه نشان داده شد كه مهار NK1R در سلولها تومورى KMM-1 موجب توقف بيشروى جرخه سلولى و در نتيجه تجمع جمعيت

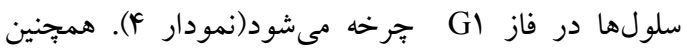
بررسى محتواى DNA سلولى آشكار ساخت كه داروى
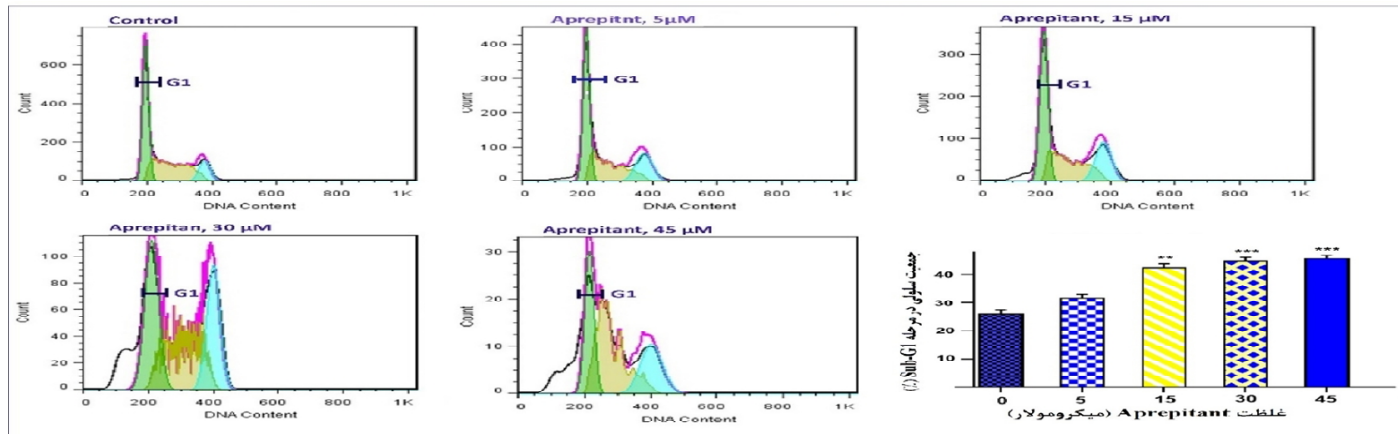

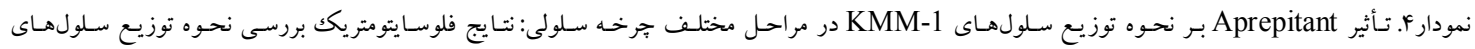

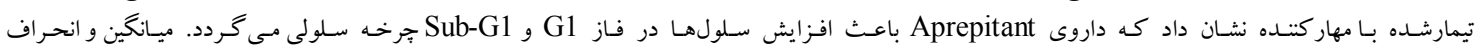
معيـار نتسايج حاصـل از سـه ران كسارى مختلـف (mean \pm SD) محاسبه و

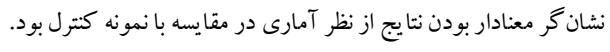

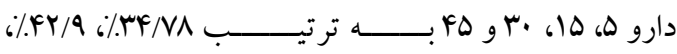

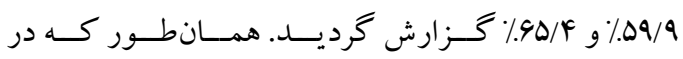

Aprepitant نمـــودار هـ نشـــان داده شـــده اســت، داروى

در القـاء آيويتـوز در سـلول هـاى مشـتق از مالتيـل ميلومـا

$$
\text { داراى روند وابسته به دوز است. }
$$

داروى Aprepitant منجــــــــه القــاء آيو يتـوز در سـلول -

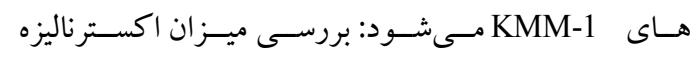
شدن فسفاتيديل سـرين بـر سـطح سـلولهـاى تيمارشـده بـا

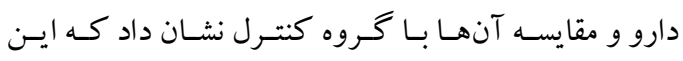
مارو قــادر بـــه القــاء آيويتـــوز در رده ســلولى KMM-1

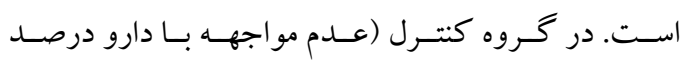

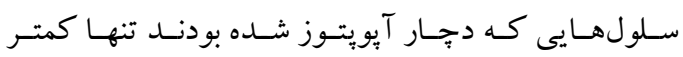

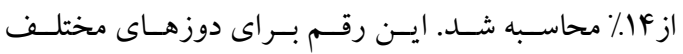




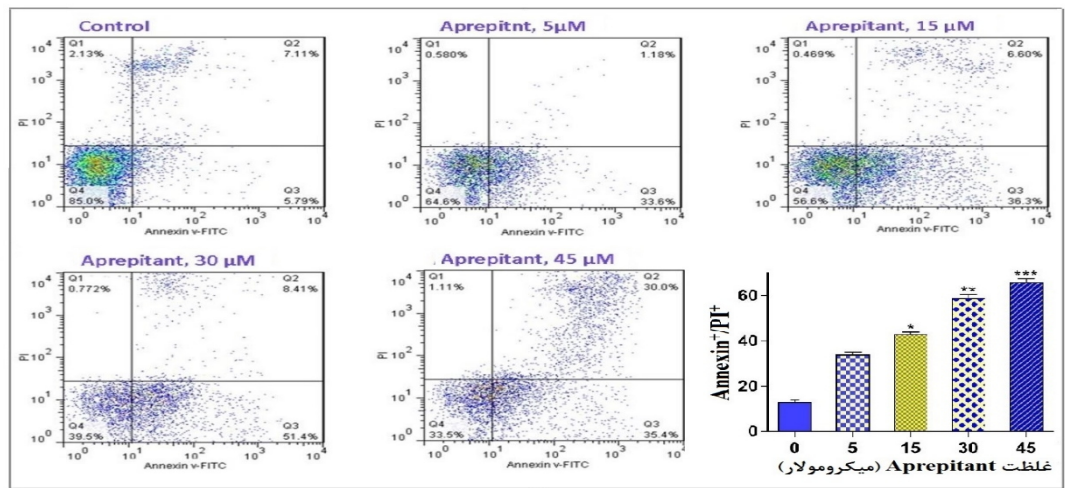

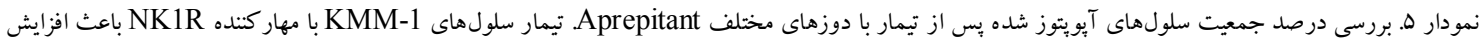

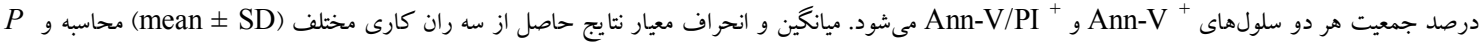

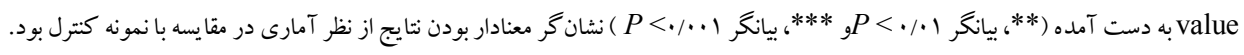

همراه است. به دليل افزايش بيان زن Bax و كاهش بيـان Bcl-2، نسبت Bax/Bcl-2 در سلولهاى مواجهشــه بـا دوزهـاى هو و 10 ميكرومولار نسبت به سلولهاى كنترل با افزايش همراه بوده است

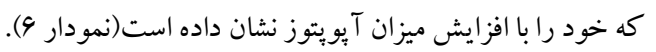

افزايش بيان Bax و كاهش بيان Bcl-2 به دنبال تيمار رده سلولى

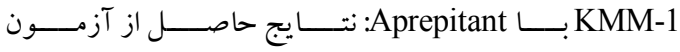
quantitative Real time RT-PCR

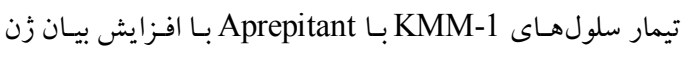
برو آيو يتو تيك Bax و كاهش بيان زن آنتى آيو يتوتيكك بcl-2

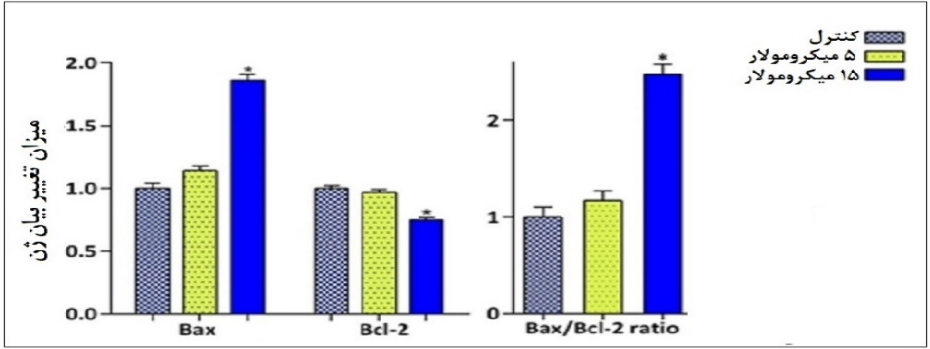

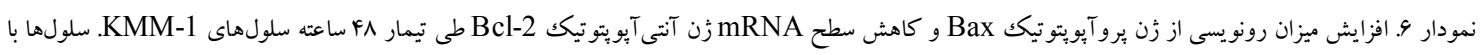

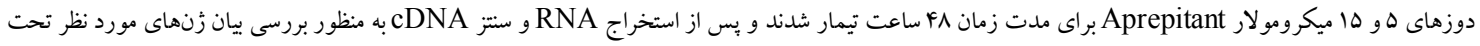

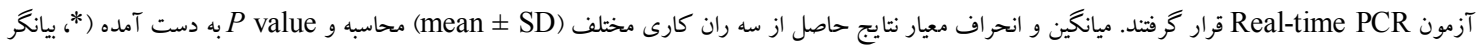

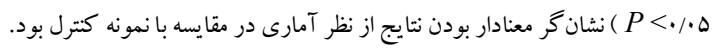

كاهش فعاليـت متابوليـك و تعـداد سـلولهـاى زنــده شـده بـود. بحث

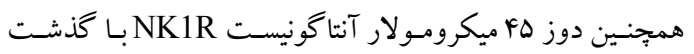
تمامى نتايج به دست آمده از اين بررسى، تأييدكننده تأثير كذارى

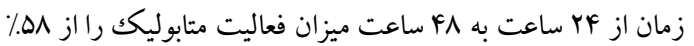

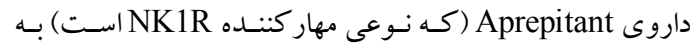

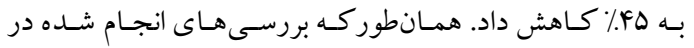
عنوان يكك داروى سايتو تو كسيك و آنتى بروليفراتيو براى سلول-

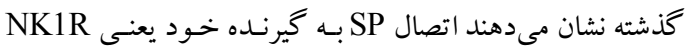
هاى KMM-1 مشتق از مالتييل ميلوما است. به طسورى كـه نتايج

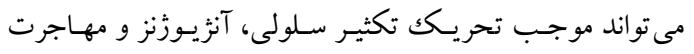

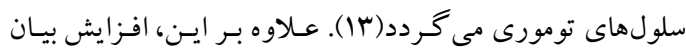
حاصل از تستهاى ترييانبلو و MTT نشان دادند، با افزايش دوز

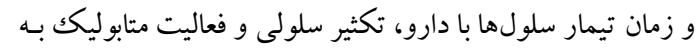
بر سطح سلولهاى تومورى نسبت به سلولهاى نرمال نيز

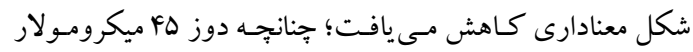

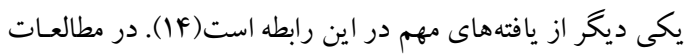
Aprepitant

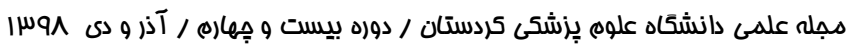




$$
\begin{aligned}
& \text { تكثير سلولى موجب فعال شدن مكانيسمهاى آيويتوز در ايسن رده }
\end{aligned}
$$

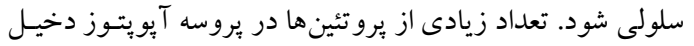

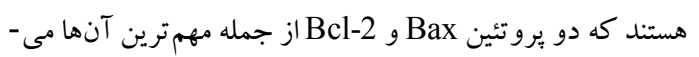

$$
\begin{aligned}
& \text { باشند. برخلاف Bax كه برو تئينى يرو آيو يتوتيكك است، Bcl-2 }
\end{aligned}
$$

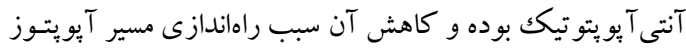

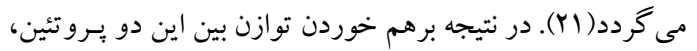

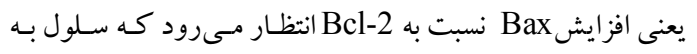

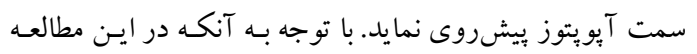

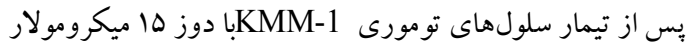

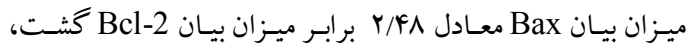

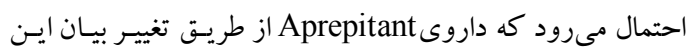

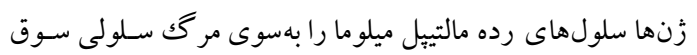

$$
\begin{aligned}
& \text { داده باشد. } \\
& \text { نتيجه كيرى } \\
& \text { مسى تسوان نتيجهـ كرفـت؛ مهـار NK1R بـا استفاده از داروى } \\
& \text { Aprepitant } \\
& \text { تومورى KMM-1 شده و به دنبال آن از ميزان تكثير و بقـاء ايـن }
\end{aligned}
$$

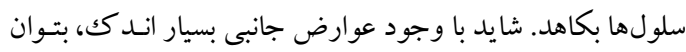

$$
\begin{aligned}
& \text { از Aprepitant به عنوان دارويى جديد در عرصه درمـان بيمـاران } \\
& \text { مبتلا به مالتييل ميلوما استفاده كرد. ضـمنا بررسى هـاى بيشتر در }
\end{aligned}
$$

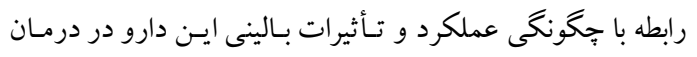

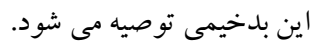

$$
\begin{aligned}
& \text { تشكر و قدردانى }
\end{aligned}
$$

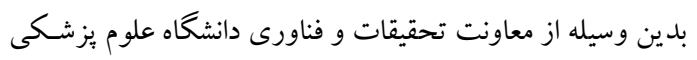

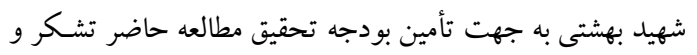

$$
\begin{aligned}
& \text { قدردانى مى گردد. } \\
& \text { فيبروبلاست نيست (11). }
\end{aligned}
$$

\section{References}

1. Seckinger A, Delgado JA, Moser S, Moreno L, Neuber B, Grab A, et al. Target expression, generation, preclinical activity, and pharmacokinetics of the BCMA-T cell bispecific antibody EM801 for multiple myeloma treatment. Cancer cell. 2017;31(3):396-410.

2. Steinbach M, Richards T, Faiman B, editors. Strategies for Selecting the Optimal Treatment in Newly Diagnosed Multiple Myeloma Patients. Seminars in Oncology Nursing; 2017: Elsevier. 
3. Attal M, Harousseau J-L, Leyvraz S, Doyen C, Hulin C, Benboubker L, et al. Maintenance therapy with thalidomide improves survival in patients with multiple myeloma. Blood. 2006;108(10):3289-94.

4. Spencer A, Prince HM, Roberts AW, Prosser IW, Bradstock KF, Coyle L, et al. Consolidation therapy with low-dose thalidomide and prednisolone prolongs the survival of multiple myeloma patients undergoing a single autologous stem-cell transplantation procedure. Journal of Clinical Oncology. 2009;27(11):1788-93.

5. Mihelic R, Kaufman J, Lonial S. Maintenance therapy in multiple myeloma. Leukemia. 2007;21(6):1150.

6. Kumar SK, Dispenzieri A, Lacy MQ, Gertz MA, Buadi FK, Pandey S, et al. Continued improvement in survival in multiple myeloma: changes in early mortality and outcomes in older patients. Leukemia. 2014;28(5):1122.

7. Esteban F, Munoz M, Gonzalez-Moles M, Rosso M. A role for substance P in cancer promotion and progression: a mechanism to counteract intracellular death signals following oncogene activation or DNA damage. Cancer and metastasis reviews. 2006;25(1):137-45.

8. DeFea K, Zalevsky J, Thoma M, Dery O, Mullins R, Bunnett N. $\beta$-Arrestin-dependent endocytosis of proteinase-activated receptor 2 is required for intracellular targeting of activated ERK1/2. The Journal of cell biology. 2000;148(6):1267-82.

9. Luo W, Sharif TR, Sharif M. Substance P-induced mitogenesis in human astrocytoma cells correlates with activation of the mitogen-activated protein kinase signaling pathway. Cancer Research. 1996;56(21):4983-91.

10. Muñoz M, Berger M, Rosso M, Gonzalez-Ortega A, Carranza A, Coveñas R. Antitumor activity of neurokinin-1 receptor antagonists in MG-63 human osteosarcoma xenografts. International Journal of oncology. 2014;44(1):137-46.

11. Berger M, Neth O, Ilmer M, Garnier A, Salinas-Martín MV, de Agustín Asencio JC, et al. Hepatoblastoma cells express truncated neurokinin-1 receptor and can be growth inhibited by aprepitant in vitro and in vivo. Journal of hepatology. 2014;60(5):985-94.

12. Razani E, Bayati S, Safaroghli Azar A, Bashash D, Ghafari A. Anti-cancer effect of aprepitant on $\mathrm{Nb} 4$ leukemic cells. Journal of Babol University of Medical Sciences. 2017;19(10):28-34.

13. Rosso M, Munoz M, Berger $M$. The role of neurokinin-1 receptor in the microenvironment of inflammation and cancer. The Scientific World Journal. 2012;2012.

14. Zhou J, Ling J, Song H, Lv B, Wang L, Shang J, et al. Neurokinin-1 receptor is a novel positive regulator of $\mathrm{Wnt} / \beta$-catenin signaling in melanogenesis. Oncotarget. 2016;7(49):81268.

15. Muñoz M, Pérez A, Rosso M, Zamarriego C, Rosso R. Antitumoral action of the neurokinin-1 receptor antagonist L-733 060 on human melanoma cell lines. Melanoma research. 2004;14(3):183-8.

16. Gillespie E, Leeman SE, Watts LA, Coukos JA, O'Brien MJ, Cerda SR, et al. Truncated neurokinin-1 receptor is increased in colonic epithelial cells from patients with colitisassociated cancer. Proceedings of the National Academy of Sciences. 2011;108(42):17420-5. 17. Ramkissoon SH, Patel PS, Taborga M, Rameshwar P. Nuclear factor- $\kappa B$ is central to the expression of truncated neurokinin-1 receptor in breast cancer: implication for breast cancer cell quiescence within bone marrow stroma. Cancer research. 2007;67(4):1653-9.

18. Bayati S, Razani E, Bashash D, Safaroghli-Azar A, Safa M, Ghaffari SH. Antileukemic effects of neurokinin-1 receptor inhibition on hematologic malignant cells: a novel therapeutic potential for aprepitant. Anti-cancer drugs. 2018;29(3):243-52. 
19. Muñoz M, Rosso M. The NK-1 receptor antagonist aprepitant as a broad spectrum antitumor drug. Investigational new drugs. 2010;28(2):187-93.

20. Su Z, Yang Z, Xu Y, Chen Y, Yu Q. Apoptosis, autophagy, necroptosis, and cancer metastasis. Molecular cancer. 2015;14(1):48.

21. Bayati S, Bashash D, Ahmadian S, Safaroghli-Azar A, Alimoghaddam K, Ghavamzadeh A, et al. Inhibition of tachykinin NK 1 receptor using aprepitant induces apoptotic cell death and G1 arrest through Akt/p53 axis in pre-B acute lymphoblastic leukemia cells. European journal of pharmacology. 2016;791:274-83. 